\title{
Sosyal Bilgiler Dersi Kazanımlarının Kültürel Yaşam Üzerindeki Etkilerine İlişkin Öğretmen Algıları
}

\section{The Teachers' Perceptions of the Gains of Social Studies Lessons upon Cultural Life}

\section{Erol KOÇOĞLU*}

Öz: İlk insanın yaradılışına kadar uzun bir geçmişe sahip olan kültür, bireyin yaşadığı ortamda geçirdiği yaşamsal evrelerle beraber sürekli bir değişim halindedir. Bu değişim kültürünü oluşturan maddi ve manevi unsurların farklılaşmasını beraberinde getirmektedir. Farklılaşan bu unsurlara ayak uydurmak gayreti içerisinde olan birey, bir takım yaşamsal tercihlerini yeniden gözden geçirmek zorunda kalmaktadır. Bireyin kültürel yaşamının belirleyiciliği üzerinde etkili olan birçok disiplin ve bu disiplinlere ait kazanımlar vardır. $\mathrm{Bu}$ çalışma alanlarından biri de sosyal bilgilerdir. Bu araştırmanın amacı, sosyal bilgiler öğretmenlerinin görüşlerine göre, sosyal bilgiler dersi öğretim programında yer alan kazanımların kültürel yaşam üzerindeki etkilerini belirlemektir. Araştırma grubunu Diyarbakır, Mardin, Muş ve Erzurum da ortaokullarda görev yapan 100 sosyal bilgiler öğretmenleri oluşturmaktadır. Sosyal bilgiler öğretmenlerinin görüşleri, açık uçlu sorulardan oluşan yarı yapılandırılmış anket formu ile alınmıştır. Elde edilen veriler, nitel veri analizi tekniğinden yararlanılara çözümlenmiştir. Araştırma bulguları, sosyal bilgiler öğretmenlerinin sosyal bilgiler dersinde yer alan kazanımların kültürel yaşam üzerindeki etkilerine ilişkin farklı algılara sahip olduklarını, bu durumu birbirinden farklı şekilde gerekçelendirdiklerini göstermektedir.

Anahtar sözcükler: Sosyal Bilgiler, kazanım, öğretmen, kültür, kültürel yaşam

Abstract: From the creation of the first man there has been a long history of culture, within an environment where individuals live together through the course of time in constant change. This process of cultural change brings material and spiritual differentiation. Any individual needing to cope with these differences needs to re-examine the variety of life-style preferences. In cultural life there is influence from many disciplines which affect the individual's life related to individual gains. This area of study is one of the areas of research in social studies. The aim of this study, obtaining the opinions of social studies teachers, was to determine the gains from social studies teaching upon cultural life. The research group consisted of 100 social studies secondary school teachers from Diyarbakir, Mardin, Muş and Erzurum. The opinions of these social studies teachers were obtained through open-ended questions and a semistructured questionnaire. The results obtained were analysed through qualitative information analysis techniques. The results of this research indicate that the social studies teachers have different perceptions of their impact on cultural life, these results also show their justifications vary, one from another.

Keywords: Social Sciences, objective, teacher, culture, cultural life

\section{Giriş}

Sosyal bilgiler eğitiminde, öğrenme ve öğretme süreci etkinliklerinin planlanmasında, sosyal bilgiler kavramının içeriksel analizinde, eğitim kavramını tanımlanma boyutunda (Ertürk, 1972,

\footnotetext{
* Yrd. Doç. Dr., İnönü Üniversitesi, Eğitim Fakültesi, İlköğretim Bölümü, Malatya, erolakademi@gmail.com
} 
akt.: Ültanır, 2003, 292), okulun işlevsel açıdan sorgulanmasında (Varış,1994), kazanımlara göre içerik oluşturulmasında ve pedagoji prensipleri doğrultusunda içerik tespitlerinin yapılması aşamalarında (Becker, 2001) kültür kavramı sürekli ön plâna çıkmaktadır (Ültanır, 2003, 292). $\mathrm{Bu}$ süreçte sürekli ön planda olan kültür kavramı ile ilgili çok fazla tanım yapılmıştır. Yüz altmış dört tanımın var olduğu söylenen (Kağıtçıbaşı, 2010, 35) kültürün, bu tanımlamalarındaki fazlalık, bir ölçüde tanımlanamama sorununu da beraberinde getirmiştir. Bu tanımlamalardan bir kaçı şu şekilde verilebilir:

- Kültür, bir toplumdaki yaşam şeklinin en genel yoludur (Mutlu, 2013, 816).

- Kültür, bir toplumda var olan davranış, düşünce ve duygu öğelerinin yapısal bir birleşimi sonucu ortaya çıkan bir üründür (Tezcan, 1987, akt.: Mutlu, 2013, 817).

- Kültür, özü itibariyle grup normlarının ulusal, rrksal ve etnik düzeyde ifadesinden başka bir şey değildir (Hogg, \& Vaughan, 2007, 654).

- Kültür, aletlerden ve tüketim mallarından, çeşitli toplumsal gruplaşmalar için yapılan anayasal belgelerden, insana özgü düşünce ve becerilerden, inanç ve törelerden oluşan bütünsel bir toplamdır (Malinovski, 1945, 39, akt.: Talas, 2010, 177).

Kültür ile ilgili tanımlamaları arttırmak mümkündür. Ancak bütün tanımlamaları vermek yerine, Edward Taylor'un bu gün içinde, kapsamı en geniş olan kültür tanımını vermek yeterli olacaktır (Talas, 2010, 176). Bu tanıma göre kültür, bir toplumun üyesi olarak insanın kazandığı bilgi, inanç, gelenek, sanatsal faaliyet, hukuk, ahlaki değerler ve diğer yetenek ve alışkanlıkları içeren karmaşık bir bütündür (Kottak, 2008, 46; Talas, 2010, 176). Bu karmaşık bütün içerisinde, herhangi bir toplumda yaşayan bireyin, ait olduğu toplumdaki bütün kültürel değerleri benimseyip yaşamsal daire içerisinde, bu değerlerden yararlanarak hayatına yön vermesi ve değerleri birer kültürel miras olarak algılayıp sahiplenmesi, kültürel yaşam olarak adlandırılabilir.

Bireyin kültürel yaşam sürecinde benimsediği kültürel değerlerin aktarımı, sosyal bilgiler çalışma alanı içerisinde yer alan disiplinlerden biri olan antropoloji aracılığı ile olmaktadır. Antropoloji insan ve kültürü temel alan bir bilimdir (Doğanay, 2003, 23; Ulusoy, 2009, 3). Safran (2008) antropolojinin, kültür ve kültür aktarımını ele aldığını ve antropolojinin sosyal bilgilerdersinde önemli bir yerinin olduğunu belirtmiştir. Engle ve Ochoa'e (1988, akt.: Ulusoy, 2009, 3) göre de sosyal bilgiler programı sekiz konu içermelidir (Öztürk, \& Dilek, 2003, 77). Bu konulardan biriside “kültür” dür. Sözer (1998) sosyal bilgileri, temel kültür ögelerini birçok disiplindeki çalışmalardan elde edilen bulgulardan, disiplinlerarası bir yaklaşımla seçilip yoğrularak oluşturulan bilgileri içinde barındıran ders olarak tanımlamaktadır. Ulusoy (2009)'a göre ise, sosyal bilgiler dersinde öğrencilerin geçmişini öğrenmeleri, kendi kültürlerini, başka kültürleri tanımaları ve geçmişi, gelenek, görenek ve adetleriyle kıvanç duyması bakımından oldukça önemlidir.

2004-2005 müfredat değişikliği ile birlikte amaçsal yönden bir takım farklılıkların oluştuğu birçok disiplin ve çalışma alanı bulunmaktadır. Bu çalışma alanlarından biri de, bireyin kültürel yaşamına yön veren ve kültürel yaşam içerisinde yer alan kültürel değerlerin birey tarafindan öğrenilerek benimsenmesini sağlayan sosyal bilgilerdir. Şöyle ki, değişen ilköğretim (ilkokul, ortaokul) müfradat programında sosyal bilgiler dersinin genel amac1: "Türk tarihini ve kültürünü kavramış, temel demokratik değerlerle donanmış ve insan haklarına saygıll, yaşadı̆̆ çevreye duyarl, bilgiyi deneyimlerine göre yorumlayıp sosyal ve kültürel bağlam içinde oluşturan, kullanan ve düzenleyen sosyal katılım becerileri gelişmiş, sosyal bilimcilerin bilimsel bilgiyi üretirken kullandıkları yöntemi kazanmış, sosyal yaşamda etkin, üretken haklarını ve sorumluluklarını bilen, Türkiye Cumhuriyeti vatandaşlarını yetiştirmektir" şeklinde belirtilmektedir (MEB, 2005). Ayrıca sosyal bilgiler, ABD Sosyal Bilgiler Ulusal Konseyi'nin (National 
Council Social Studies NCSS) tanımlamasına göre vatandaşlıkla ilgili yeterlilikleri kazandırmak için sosyal bilimler ve beşeri bilimlerin bütünleştirilmesinden oluşan bir çalışma alanıdır. Bu alanın temel amacı, genç insanların bağımsız bir dünyada, demokratik toplumda, kültürel farklilıkların farkında, mantıklı kararlar veren iyi bir vatandaş olmalarına yardım etmektir (NCSS, 1994, 3; Mentiş, 2004, 31). Sosyal bilgiler dersinin genel amac1 incelendiğinde, yetiştirilmesi hedef olarak alınan bireyin sahip olması gereken niteliklerden birinin "kültürel değerleri benimsemiş olma" zorunluluğu olduğu görülmektedir.

Sosyal bilgiler ilköğretimde (ilkokul ve ortaokul) ele aldığı konular bakımından çok çeşitlilik sunan bir derstir. Sosyal Bilgilerde içeriğin oluşturulmasında tarih, psikoloji, sosyoloji, antropoloji, ekonomi, coğrafya, ve siyasal bilimler gibi sosyal bilim alanlarından yararlanılmaktadır. Bununla beraber sosyal bilgiler dersi içerisinde bireylere kazandırılması gereken kültürel ve dini değerlerin aktarılmasında sosyal bilgiler din disiplininden yararlanmaktadır. Ancak bu aktarımda nesnellik ve bu değerlere karşı ön yargısız bir tutum izlenildiğinde bireylerdeki güven duygusuna zarar verilmemiş olacaktır. Sosyal bilgiler genelde dünya insanlarının tarihleri, kültürleri ve etkileşimlerini disiplinlerarası yaklaşımla konu edinmektedir (Wade, 2007; Duplass, 2007; Deveci, \& Gürdoğan-Bayır, 2011). Sosyal bilgiler dersinin kapsam bak1mından bu işlevselliğinden dolayı, bireyin kültürel anlamda gelişimini şekillendirmede kritik bir öneme sahip olduğu söylenebilir.

Sosyal bilgiler dersinin bireyin külürel yaşamı üzerindeki etkisini ve Türkiye’de 2014-2015 eğitim öğretim yılında okutulan sosyal bilgiler müfredat programında yer alan öğrenme alanı, ünitelerin verildiği tablo 1 ile örnek kazanımların verildiği tablo 2'ye bakarak görmek mümkündür.

Tablo 1. Sosyal Bilgiler Ders Programında Bireyin Kültürel Yaşamı Üzerinde Etkili Olan Öğrenme Alanları, Üniteler ve Süreleri

\begin{tabular}{|c|c|c|c|c|}
\hline \multicolumn{1}{|c|}{ Sınıf } & Öğrenme Alanı & Ünite & Kazanım sys. & Ders saati \\
\hline 4. Sınıf & Kültür ve Miras & Geçmişimi Öğreniyorum & 6 & 15 saat \\
\hline & İnsanlar, Yerler ve Çevreler & Yaşadığımız Yer & 8 & 15 saat \\
\hline \multirow{2}{*}{ 5. Sınıf } & Kültür ve Miras & Adım adım Türkiye & 8 & 15 saat \\
\cline { 2 - 5 } & İnsanlar, Yerler ve Çevreler & Bölgemizi Tanıyalım & 8 & 15 saat \\
\hline \multirow{2}{*}{ 6. Sınıf } & Kültür ve Miras & İpek Yolunda Türkler & 9 & 24 saat \\
\cline { 2 - 5 } & İnsanlar, Yerler ve Çevreler & Yeryüzünde Yaşam & 7 & 15 saat \\
\hline \multirow{2}{*}{ 7. Sınıf } & Kültür ve Miras & Türk Tarihinde Yolculuk & 8 & 27 saat \\
\cline { 2 - 5 } & İnsanlar, Yerler ve Çevreler & Ülkemizde Nüfus & 5 & 12 saat \\
\hline
\end{tabular}

Tablo 2. Sosyal Bilgiler Ders Programında Bireyin Kültürel Yaşamı Üzerinde Etkili Olan Öğrenme Alanlarına ilişkin Kazanım Örnekleri

\begin{tabular}{|l|l|}
\hline Sınıf & \multicolumn{1}{|c|}{ Kazanımlar } \\
\hline 4. Sınıf & $\begin{array}{l}\text { - Kültür ögelerinin geçmişten bugüne değişerek taşındığına ilişkin yakın çevresinden } \\
\text { kanıtlar gösterir. } \\
\text { - Yaşanmış olaylardan ve görsel materyallerden yola çıkarak, Millî Mücadele sürecinde } \\
\text { yakın çevresini ve Türkiye'yi betimler. }\end{array}$ \\
\hline 5. Sınıf & $\begin{array}{l}\text { - Görsel kanıt kullanarak Atatürk İnkılâpları öncesi ile sonrası günlük yaşamı } \\
\text { karşılaştırır. } \\
\text { - Ulusal egemenlik sembollerine değer verir. }\end{array}$ \\
\hline 6. Sınıf & $\begin{array}{l}\text { - Günümüz Türk Silahlı Kuvvetleri'ni ilk Türk devletlerinin ordusu ile ilişkilendirerek, } \\
\text { Türk Silahlı Kuvvetleri’nin önemini ve görevlerini kavrar. }\end{array}$ \\
\hline
\end{tabular}




\begin{tabular}{|l|l|l|}
\hline & $\begin{array}{l}\text { • Dönemin devlet adamları ve Türk büyüklerinin hayatından yararlanarak ilk Türk- } \\
\text { İslam devletlerinin siyasal, sosyal ve kültürel özelliklerine ilişkin çıkarımlarda bulunur. } \\
\text { • }\end{array}$ \\
\hline 7. Sınıf & $\begin{array}{l}\text { • Türkiye Selçukluları döneminde Türklerin siyasal mücadeleleri ve kültürel } \\
\text { faaliyetlerinin Anadolu'nun Türkleşme sürecine katkılarını değerlendirir. } \\
\text { - Seyahatnamelerden hareketle Türk kültürüne ait unsurları örneklendirir. }\end{array}$ & \\
\hline
\end{tabular}

2004-2005 yıllarında ilköğretim (ortaokul, ilkokul) müfredat programlarındaki değişiklik sosyal bilgiler dersinde kazanım ve içerik öğeleri başta olmak üzere, öğrenme-öğretme süreci ve s1nama durumları da öğrenci merkezli bir takım etkinliklerle yeniden düzenlenmiştir. Yapılan bu değişiklikler, sosyal bilgiler dersi müfradatına yeni çalışma alanlarının eklemesini sağlamakla beraber; daha önceden var olan çalışma alanlarının da kazanım açısından yeniden ele alınıp değerlendirilmesine olanak sağlamıştır. Değerlendirilen bu çalışma alanlarından biri de, bireyin kültürel yaşamı üzerinde belirgin bir etkiye sahip olan kültürel miras eğitiminin çalışma alanıdır. Bu çalışma alanıyla ilgili yapılan düzenlemeler sonucunda, sosyal bilgiler dersinin bireyin kültürel yaşamı üzerindeki etki düzeyini belirlemek için, bu çalışmanın yapılması gerekliliği ortaya çıkmıştır.

\section{Araştırmanın Amacı}

Araştırmanın genel amac1, sosyal bilgiler öğretmeninin görüşleri doğrultusunda Türkiye'de ilkokul ve ortaokullarda okutulan sosyal bilgiler dersine ilişkin programlarda yer alan kazanımların bireyin yaşamına kültürel açıdan etkilerini belirlemek, sosyal bilgiler öğretmenlerinin değerlendirmelerini incelemek ve ulaşılan sonuçlar eşliğinde önerilere yer vermektir. Bu genel amaç çerçevesinde aşağıdaki sorulara cevap aranmıştır:

- Sosyal bilgiler eğitimi programlarında yer alan kazanımların bireyin kültürel yaşamı üzerinde etkili olduğunu düşünüyor musunuz?

- Sosyal bilgiler eğitimi programlarında yer alan kazanımlar, size göre kültürel yaşamı daha çok hangi açıdan etkilemektedir?

- Sosyal bilgiler eğitimi programlarında yer alan kazanımların birbirinden farklı disiplinlere yönelik olarak hazırlanması, bireyin kültürel yaşama bakış açısı üzerinde etkili midir?

- Sosyal bilgiler ders programında kültürel yaşama yönelik, yer alan kazanımlar, sosyal bilgiler dersinde yer alan disiplinlerden hangisini sizce daha çok ön plana çıkarmaktadır?

- Sosyal bilgiler eğitimi programlarında yer alan kazanımlarda, ön plana çıkan kültürel değerler nelerdir?

\section{Yöntem}

\section{Araştırma Modeli}

Sosyal bilgiler dersi kazanımlarının kültürel yaşam üzerindeki etkilerine ilişkin öğretmen alg1larının belirlenmesine yönelik bu araştırma, nitel araştırma yaklaşımına dayalı yarı yapılandırılmış görüşme yöntemiyle gerçekleştirilmiştir. Creswell (1998) nitel araştırmayı, sosyal yaşamı ve insanla ilgili problemleri kendine özgü metodlarla sorgulayarak, anlamlandırma süreci olarak ifade etmektedir. Nitel araştırma sürecinde araştırmacı bütüncül bir araştırma tablosu ortaya koyarak; kelime analizleri, detaylı katılımcı görüşme raporları kullanır ve araştırmayı doğal ortamda düzenler. Nitel araştırmada genel olarak takip edilen araştırma süreci parçadan bütünedir [tümevarım]. Genel itibari ile nitel araştırmacı gözlem, görüşme ve dokümanlardan yola çıkarak kav- 
ramları, anlamları ve ilişkileri açıklayarak süreci sürdürür (Merriam, 1998; Yıldırım, \& Şimşek, 2008).Yarı yapılandırılmış görüşmelerde ise, görüşme soruları önceden belirlenmiş görüşme durumlarını kapsamaktadır (Balc1, 2004).

$\mathrm{Bu}$ araştırma da durum çalışması modeli kullanılmıştır. Durum çalışması modeli "güncel bir olgunun gerçek yaşam bağlamında, özellikle bağlam ve olguların sınırlarının kesin olarak belli olmadı̆̆ l durumlarda görgül olarak araştırılması" şeklinde ifade etmektedir (Yin, 1994, 13; Merriam, 1998, 27).

\section{Çalışma Grubu}

Araştırmada çalışma grubunu, Diyarbakır, Mardin, Muş ve Erzurum'daki ortaokullarda görev yapan 100 sosyal bilgiler öğretmeni oluşturmaktadır. Araştırmacının, bu illerde görev yapan sosyal bilgiler öğretmenlerine, yapılan bir seyahatte ulaşma imkânını rahatlıkla bulması ve bu illerde bulunan sosyal bilgiler öğretmenlerine ulaşmak, araştırmacıya araştırmanın güvenirliği açısından kolaylık sağladığı için çalışma grubu üyeleri bu illerden seçilmiştir. Çalışma grubu üyelerinin 40'1 Erzurum, 30'u Diyarbakır, 15'i Mardin ve 15'i Muş illlerimizde görev yapan sosyal bilgiler öğretmenleridir. Çalışma grubu üyelerinin $35^{\prime}$ 'i kadın $65^{\prime}$ i Erkek öğretmenlerden oluşmaktadır.

\section{Veri Toplama Aracı}

Araştırmanın kuramsal boyutu oluşturulduktan sonra sosyal bilgiler öğretmenlerinin sosyal bilgiler dersi kazanımlarının kültürel yaşam üzerindeki etkilerine ilişkin görüşlerini almak üzere yarı yapılandırılmış görüşme formu hazırlanmıştır. Görüşme formu hazırlanırken öncelikle sorulacak sorular belirlenmiştir. Sorular oluşturulurken kolay anlaş1labilecek sorular yazma, açık uçlu sorular sorma, odaklı sorular hazırlama, yönlendirmekten kaçınma, çok boyutlu sorular sormaktan kaçınma ve soruları mantıklı bir biçimde düzenleme gibi ilkelere (Yıldırım, \& Şimşek, 2008) dikkat edilmiştir. Görüşme formu hazırlandıktan sonra bir sosyal bilgiler öğretmeni ile ön görüşme yapılmış, görüşme tamamlandıktan sonra öğretmenin görüşme sorularına verdiği yanıtlar çözümlenerek dökümü yapılmıştır. Anlaşılmayan soru maddeleri değiştirilmiştir. Ön görüşmeye alınan bu öğretmen araştırma kapsamı dışında tutulmuştur.

Araştırmada kullanılacak olan görüşme formu, Fırat Üniveristesi ve Yıldız Teknik Üniversitesi Eğitim Fakültelerinde görev yapan alan uzmanlarına, içerik geçerliliğini sağlamak amacıyla görüşlerine sunulmuştur. Alan uzmanlarından gelen görüş ve öneriler doğrultusunda görüşme formuna son şekli verilmiştir. Görüşme formunda 5 soru yer almaktadır. Görüşmelerin gerçekleştirilebilmesi için araştırma kapsamındaki her bir sosyal bilgiler öğretmeni ile önceden görüşme yapılarak randevu alınmıştır. Görüşmede görüşme formunda yer alan sorular öğretmene sırasıyla sorulmuş ve öğretmenden rahat bir şekilde soruları cevaplaması talep edilmiştir. Öğretmenin sorulara verdiği yanıtlar, araştırmacı tarafından yazılı olarak kaydedilmiştir.

\section{Verilerin Analizi}

Görüşme formu ile ilgili çözümlemeler nitel boyutta gerçekleştirilmiştir. Bilgisayar destekli nitel veri analizi yapılmıştır. Verilerin analizinde ve modellerin oluşturulmasında NVivo 8 programından yararlanılmıştır. Kodlamalar araştırmacıların ortak görüşleri doğrultusunda oluşturulmuştur. Bu çerçevede, sosyal bilgiler öğretmenlerinin, sosyal bilgiler dersi kazanımlarının kültürel yaşam üzerindeki etkilerine yönelik görüşleri betimlenmeye ve içerik analizi yöntemiyle belli temalar altında bu görüşler gruplanarak çözümlenmeye çalışılmıştır.

Araştırmanın güvenirliğini sağlamak için, araştırmada ulaşılan uzman görüşüne başvurulmuştur. Araştımacı ve uzmanlar tarafından öncelikle ana temalar ardından bunlara bağlı tema ve 
alt temalar oluşturulmuştur. Çözümlemeler sonucunda ortaya çıkan temalar aralarındaki bağları gösterir şekilde modellenmiş ve görselleştirilmiştir. Modelde yer alan ilişkileri gösteren temay1 söyleyen kişi sayısı (frekansını) belirlenmiştir.

Araştırmacıların ve uzmanın, temalarda yer alması gereken görüşlere ilişkin değerlendirmeleri karşılaştırılarak "görüş birliği" ve "görüş ayrıliğı" sayıları tespit edilmiştir. Araştırmacı dışında iki uzmanla birlikte analizler yapılıp, Miles ve Huberman'ın (1994) formülüne göre araştırmacılar arasındaki uyum hesplanmıştır. Bu hesaplama sonucunda,

$\mathrm{P}=($ 83/83+1) x $100=\% 92$ olarak hesaplanmıştır.

\section{Bulgular ve Yorumlar}

Sosyal bilgiler öğretmenlerinin görüşleri temelinde, verilerin analizi ile elde edilen bulgular aşağıda yöneltilen sorulara ilişkin oluşan alt başlıklar altında yer almaktadır.

\section{Sosyal Bilgiler Dersi Kazanımlarının Kültürel Yaşam Üzerindeki Etkilerine İlişsin Durum}

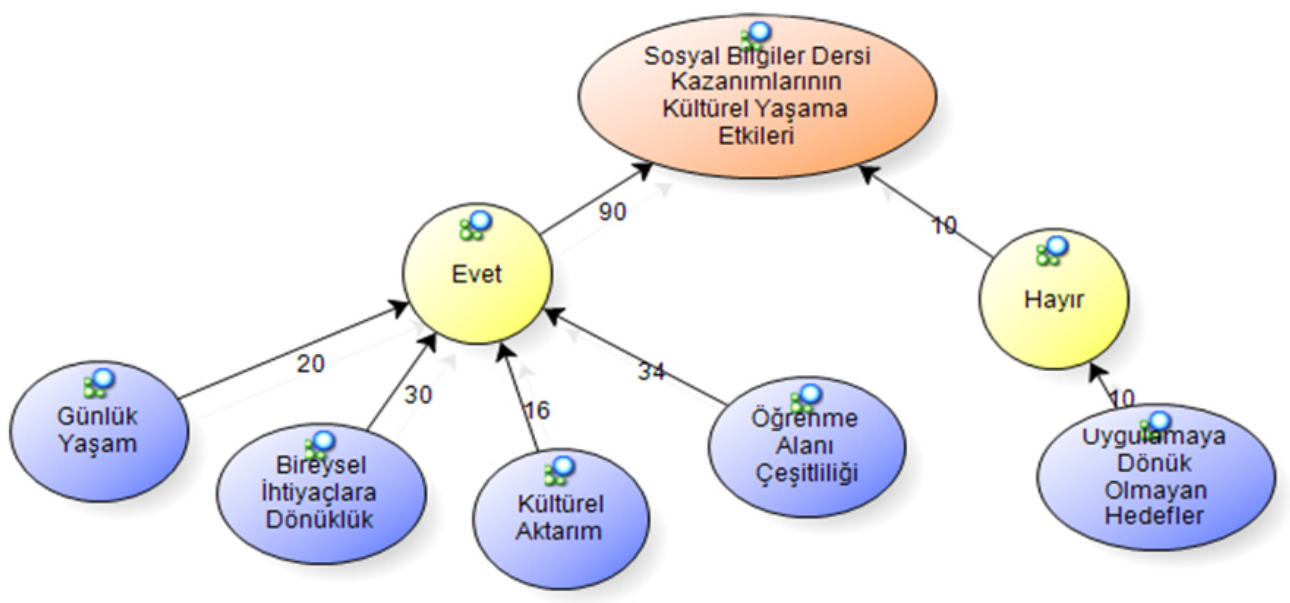

Fig. 1. Sosyal Bilgiler Dersi Kazanımlarının Kültürel Yaşama Etkilerine İlişkin Sonuçlar

Yapılandırmacı eğitim anlayışına göre programlarda öğrenci merkezli bir değişim sürekli olarak yapılmasına rağmen, bu değişimlere yönelik kazanımların öğrenciye aktarımında buna pek de dikkat edildiği söylenemez. Bireyin kültürel değer algısının şekillenmesinde, çalışma grubu üyelerinin bu temada yaparak yaşayarak öğrenebilecekleri bir öğrenme ortamı eksikliğine "Hayır" diyerek vurgu yaptıklarını görmekteyiz.

Türkiye'de sosyal bilgiler dersi programlarında yer alan kazanımların kültürel yaşam üzerindeki etkilerine ilişkin sosyal bilgiler öğretmenlerinin görüşleri iki şekilde ele alınmıştır. Sosyal bilgiler dersi kazanımlarının kültürel yaşam üzerindeki etkisini, günlük yaşam, bireysel ihtiyaçlara dönüklük, öğrenme alanı çeşitliliği ve kültürel aktarımdan kaynaklanan sebeplerden dolayı "Evet"; sosyal bilgiler dersi kazanımlarının kültürel yaşam üzerindeki etkisinin programlarda yer alan hedeflerin uygulamaya dönük olmamasından dolayı "Hayır" alt temalarının öğretmenler tarafindan ön plana çıkarıldığ 1 görülmektedir (Fig. 1).

$\mathrm{Bu}$ konuda sosyal bilgiler öğretmenlerinin görüşleri aşağıdaki şekilde örneklendirilebilir:

"Sosyal bilgiler dersi kazanımlarının bireyin kültürel yaşamına etkililiğine ilişkin sorduğunuz soruyu biraz açmak istiyorum. Bana göre bu dersin kazanımları sadece kültürel yaşam üzerinde değil demokratik 
yaşam, sosyal yaşam ve ekonomik yaşamı da belli oranda etkilendiği kantsindayım. Yani sınırsız bir etkiden söz edebilirim. Bireyin kültürel yaşamı, bireyin kültürel değerleri ögrenmesi ve sahiplenmesi ile oluşur. Bireyin kültürel değerlerini ögrenmesi ve sahiplenmesi üzerinde sosyal bilgiler dersi kazanımlarının yadsınamaz düzeyde etkisi vardır. Bundan dolayı Sosyal bilgiler dersi kazanımları da bir kültür taşımacılı̆̆g rolü üstlendiklerini söyleyebilirim” (Sosyal Bilgiler Öğretmeni, 17; kültürel yaşam).

"Bireyin kültürel yaşam kavramının sübjektif algı gerektiren bir kavram olmaslyla birlikte, bireylerin değişen ihtiyaçlarına göre şekillendiği düşüncesindeyim. Bu kavram üzerinde sadece sosyal bilgiler dersinin kazanımlarının etkisi olduğunu söylemek büyük bir yanilgiya düşmek olacaktır. Diğer derslerin kazanımlarının olduğu gibi sosyal bilgiler dersi kazanımlarının da bireyin günlük yaşamında bir takım ihtiyaçlarını karşılamasına katkı sağlaması dolyısıyla kazanımların kültürel yaşam üzerindeki etkililiğinden söz edebiliriz” (Sosyal Bilgiler Öğretmeni, 99; günlük yaşam).

"Sosyal bilgiler dersinde yer alan kazanımların bireyin kültürel yaşamı üzerinde etkili olduğunu düşünmüyorum. Çünkü, sosyal bilgiler dersinde yer alan kazanımlar daha çok teorik öğrenmeler sağladı̆̆ından dolayı kalıcılık düzeyinin, çok düşük olduğunu düşünüyorum” (Sosyal Bilgiler Öğretmeni, 8; uygulamaya dönük olmayan hedefler).

\section{Sosyal Bilgiler Eğitimi Programlarında Yer Alan Kazanımların, Kültürel Yaşamı Etkileme Yönü Durumu}

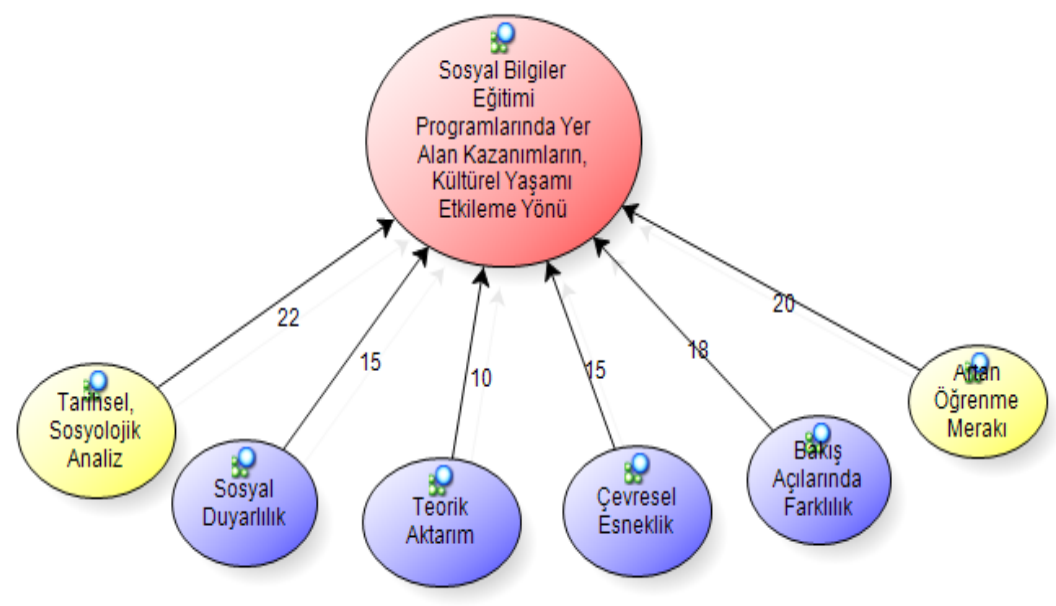

Fig. 2. Sosyal Bilgiler Eğitimi Programlarında Yer Alan Kazanımların, Kültürel Yaşamı Etkileme Yönüne İlişkin Sonuçlar

Sosyal bilgiler eğitimi programlarında yer alan kazanımların bireyin kültürel yaşamını birçok yönüyle etkilediğini görmekteyiz. Sosyal bilgiler dersi kazanımlarının kültürel yönde böyle bir niteliğe sahip olmasının dersin öğreticileri olan öğretmenler tarafından bilinmesi ve bu bilinçle aktarılması sosyal bilgiler dersini kültürel açıdan niteliğini arttırabilir. 
"Sosyal bilgiler eğitimi dersi programlarında yer alan kazanımların, kültürel yaşamı etkileme yönü” şeklinde tanımlanan bu temada, sosyal bilgiler öğretmenlerinde sosyal bilgiler dersi kazanımlarının kültürel yaşamı etkileme yönü olarak; tarihsel sosyolojik analiz (f:22), artan öğrenme merakı (f:20), bakış açılarında farklılık (f:18), çevresel esneklik (f:15), sosyal duyarlık (f:15) ve teorik aktarım (f:10) olarak sıralamışlardır (Fig. 2). Çalışma grubunu oluşturan öğretmenlerden bazılarının görüşleri aşağıdaki gibidir:

\begin{abstract}
"Sosyal bilgiler eğitimi dersi programlarında yer alan kazanımlar kültürel yaşamı birçok yönü ile etkilemekle beraber, bireyin kültürel yaşamının şekillenmesine en çok katkı sağlayan yönünün bireyde sahip olduğu çevreye ve değerlere karşı ögrenme merakının artmasını sağlamasıdır. Artan ögrenme merakı bireyin aynı zamanda etkin bir şekilde ögrenmesine de katkı sağlayacă̆ düşüncesindeyim" (Sosyal Bilgiler Öğretmeni, 21; artan öğrenme merakı).

"Birey yaşadı̆̆ toplumdan bağımsız olarak kültürel yaşamını şekillendirmez. Öncelikle bunu bilerek sorunuza cevap vermek istiyorum. Gerek sosyal bilgiler dersi gerekse diğer temel dersler olsun her birinin kültürel yaşamı etkileme yönü birbirinden farklıdır. Zaten kültürel yaşamı da zenginleştiren bu farklllıklardır. Sosyal bilgiler dersinin ise kültürel yaşamı etkileme olarak, ön plana çıkan yönünün bireye olgular, olaylar, kavramlar ve konularla ilgili ön yargılarından bağımsız farklı bakış açıları kazandırmasıdır. Bu durum bireyde yaratıcı ve ıraksak düşünce biçiminin ortaya çıkmasını sağlayacaktır" (Sosyal Bilgiler Öğretmeni, 49; bakış açısında farklılık).
\end{abstract}

\title{
Sosyal Bilgiler Dersinde Farklı Disiplinlere Yönelik Kazanımların Bireyin Kültürel Yaşamı Üzerindeki Etkililiğine İlişskin Durum
}

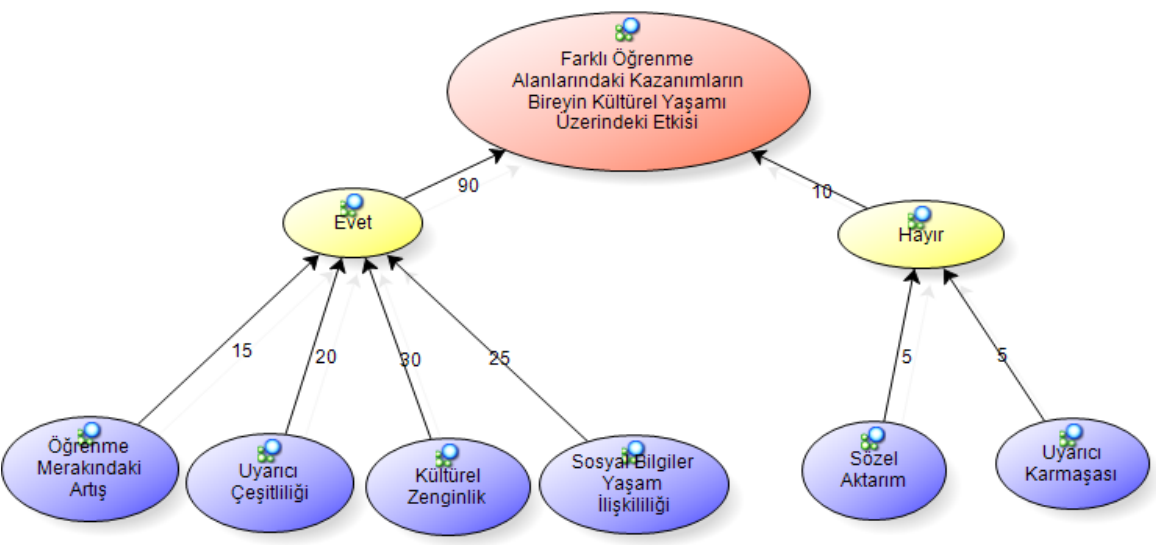

Fig. 3. Sosyal Bilgiler Dersinde Farklı Öğrenme Alanlarına Yönelik Kazanımların Bireyin Kültürel Yaşamı Üzerindeki Etkililiğine İlişkin Sonuçlar

Sosyal bilgiler dersinin birden çok disiplinden oluşması bireyin kültürel yaşamı üzerinde olumlu etkiye sahip olduğu kadar olumsuz etkileri de olabilir. Çünkü bir kazanımlar sentezinden oluşan sosyal bilgiler dersi, çalışma alanı farklılıkları dikkate alınmadan aktarımı yapılırsa bireyin kültürel yaşamı üzerinde bilinçli değerlenme algısının ortadan kalkmasına sebep olabilir.

Çalışma grubunu oluşturan sosyal bilgiler ögretmenlerinin "sosyal bilgiler dersinde farklı 
disiplinlere yönelik kazanımların bireyin kültürel yaşamı üzerindeki etkililiğine ilişkin durumun" incelendiği bu temada, "Evet" ve "Hayır" şeklinde farklılaştıkları gözlemlenmektedir. "Evet" yanıtını veren sosyal bilgiler öğretmenleri bu durumu, kültürel zenginlik (f:30), sosyal bilgiler yaşam ilişkisi (f:25), uyarıcı çeşitliliği (f:20), ve öğrenme merakındaki artışla (f:15) açıklarken; "Hayır" yanıtını veren öğretmenler ise sözel aktarım (f:5) ve uyarıcı karmaşası (f:5) ile açıkladıkları görülmektedir (fig. 3). Sosyal bilgiler öğretmenlerinden bazılarının bu temaya ilişkin görüşleri şu şekilde örneklendirilebilir:

"Sosyal bilgiler dersini oluşturan farklı ögrenme alanlarına yönelik olarak hazırlanan kazanımların öğrencinin kültürel yaşamı üzerinde etkililiği kişiden kişiye değişen bir durum olsa da bana göre kesinlikle etkilidir. Çünkü sosyal bilgiler kazanımlarının tamamı hayatın kendisini içeren hayatın gerekliliklerinden kopuk olmayan ve bireye yaşamı sürecinde yardımı temele alan kazanımlardır" (Sosyal Bilgiler Öğretmeni, 11; sosyal bilgiler yaşam ilişkililiği).

"Bireyin kültürel yaşamı üzerinde sosyal bilgiler dersi kazanımlarının etkisi vardır, ancak bu kazanımların farklı ögrenme alanlarına yönelik olması bu etkililiği daha da arttırdı̆̆ düşüncesindeyim. Bu durumu, bireyin farklı uyarıcılarla edindiği birikimini kültürel yaşamına yansitması ile açıklayabiliriz” (Sosyal Bilgiler Öğretmeni, 38; kültürel zenginlik).

"Sosyal bilgileri oluşturan farklı disiplinlere ilişkin kazanımların sosyal bilgiler dersinde yer alması bireyin kültürel yaşamına olumlu açıdan bir katkı sağlamaz. Çünkü bu kazanımlar ve kazanımların oluşturduğu öğrenme alanları ögretmenler tarafindan sadece anlatım yöntemiyle olduğu gibi aktarılması, örneklendirilme açısından desteklenmemesi bu etkiyi ortadan kaldırmaktadır" (Sosyal Bilgiler Öğretmeni, 13; sözel aktarım).

\section{Kültürel Yaşama Yönelik Kazanımların Sosyal Bilgiler Dersinde Ön Plana Çıkardığı Disiplinlere İlişkin Durum}

Araştırmada yer alan "kültürel yaşam üzerinde belirleyici etkiye sahip olan kazanımların sosyal bilgiler dersinde ön plana çıkardiğı disiplinler" temasına ilişkin, çalışma grubunu oluşturan sosyal bilgiler öğretmenlerinin yedi farklı disiplini ortaya atarak farklılaştıkları figür 4'e bakıldığında söylenebilir. Sosyal bilgiler öğretmenleri bu temaya ilişkin olarak, arkeoloji (f:8), eğitim (f:10), tarih (f:25), sosyoloji (f:15), din (f:15), coğrafya (f:20) ve felsefe (f:7) disiplinlerini ön plana çıkarmışlardır (fig. 4). Sosyal bilgiler öğretmenlerinin birbirinden farklı disiplinleri ortaya çıkarmaları sosyal bilgiler dersinin geniş alan tasarımına dayalı olarak hazırlandığının göstergesi olabilir. Temaya ilişkin olarak çalışma grubu üyelerinin görüşleri şu şekilde örneklendirilebilir:

"Sosyal bilgiler dersine yönelik olarak programlarda yer alan kazanımların kültürel yaşama etkisi açısından ön plana çıkardiğı öğrenme alanları bence bir isim altında toplanması kültürel yaşamın gerekliliklerini içeren diğer ögrenme alanlarının görmemezlikten gelme anlamı taşımaktır. Bu bana göre yanlıştır. Ancak hangisini daha çok ön plana çıkarmaktadır derseniz, o zaman cevabım kesinlikle Tarih olacaktır" (Sosyal Bilgiler Öğretmeni, 78; tarih).

"Sosyal bilgiler dersinde kültürel yaşam üzerinde etkili olan kazanımla- 
rın daha çok yoğunlaştı̆̆ öğrenme alanı, bireyin yaşam koşullarını, yaşadiğı çevreyi, yaşadiğı ortamın atmosferik durumunu, ekonomik, beşeri ve kültürel etkinliklerini temele alan coğrafyadır" (Sosyal Bilgiler Öğretmeni, 65; coğrafya).

"Sosyal bilgiler dersi içerisinde yer alan her bir displin zannımca kültürel yaşam üzerinde belirleyici bir etkiye sahiptir. Ancak Sosyal bilgiler ders programlarında yer alan kazanımlar incelendiğinde bir şeyin gözden kaçırıldığını görüyorum. Diğer disiplinlere ait kültürel kazanımları oluşturan içeriğin günümüze kadar gelmesini sağlayan en önemli disiplin tabiki eğitimdir. Birey eğitim disiplini ile diğer disiplinlere ait kazanımlara yönelik etkinliklerde yapabildiğinden dolayı bu displin daha kültürel yaşama katkı açısından diğerlerinden daha önemlidir" (Sosyal Bilgiler Öğretmeni, 1; eğitim).

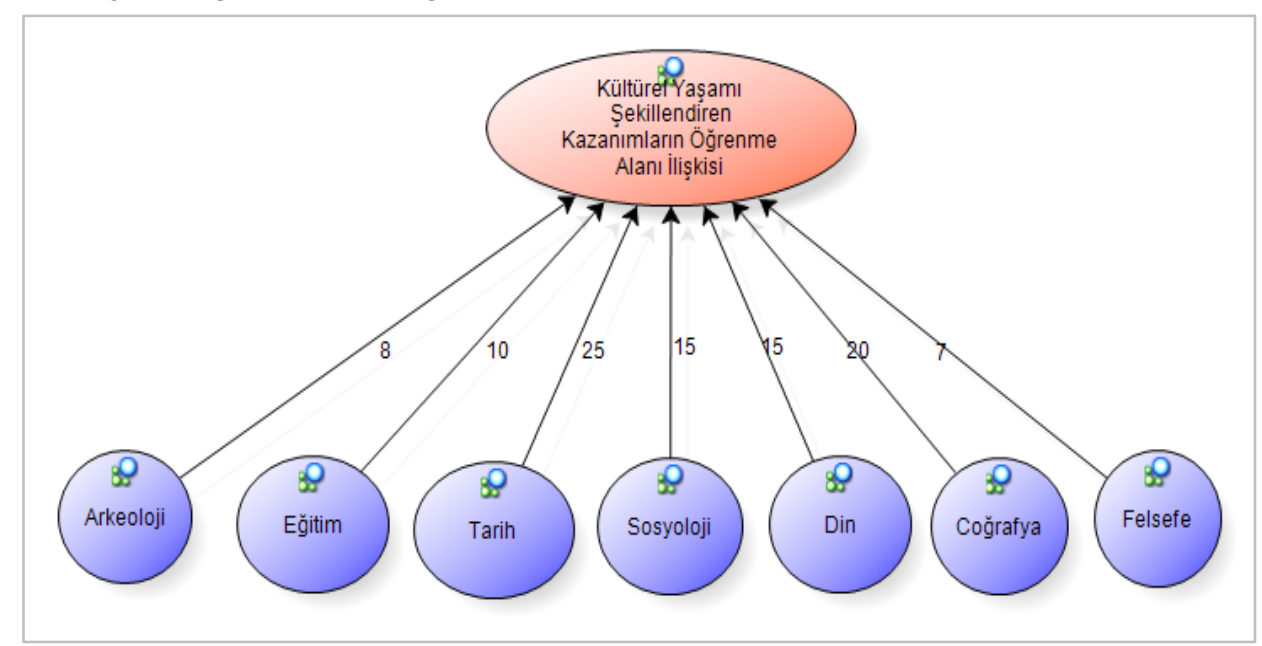

Fig. 4. Kültürel Yaşam Üzerinde Belirleyici Etkiye Sahip Olan Kazanımların Sosyal Bilgiler Dersinde Ön Plana Çıkardığı Disiplinlere İlişkin Sonuçlar

\section{Sosyal Bilgiler Dersi Programlarında Yer Alan Kazanımlarda Ön Plana Çıkan Kültürel Değerler}

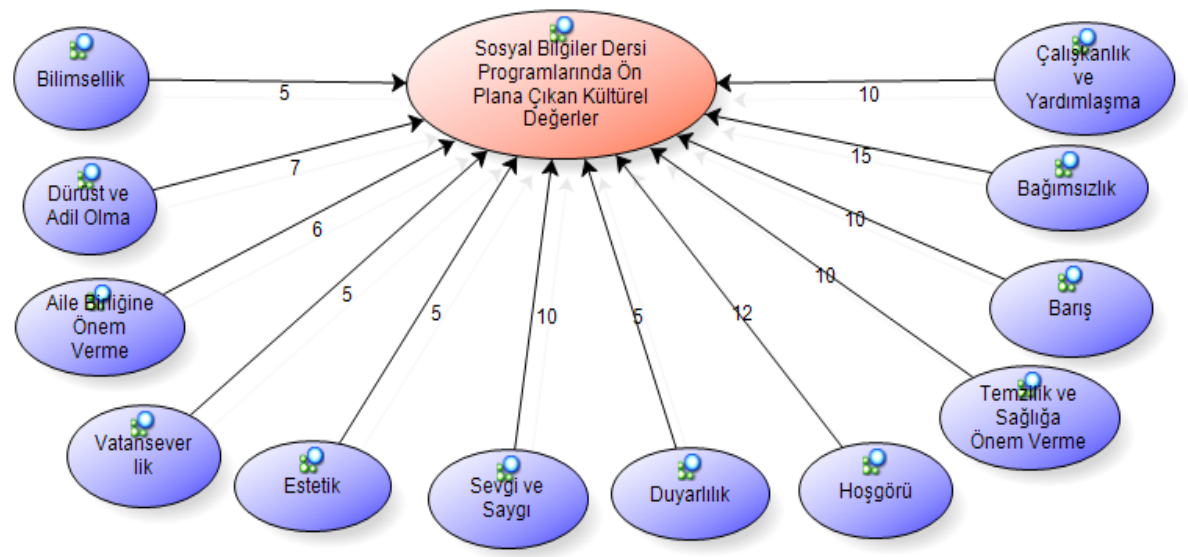

Fig. 5. Sosyal Bilgiler Dersi Programlarında Yer Alan Kazanımlarda Ön Plana Çıkan Kültürel Değerler 
"Sosyal bilgiler dersi programlarında yer alan kazanımlarda ön plana çıkan kültürel değerler" temasının irdelendiği çalışmanın bu aşamasında sosyal bilgiler öğretmenlerinin birbirinden farkl1 12 kültürel değeri ileri sürdükleri görülmektedir. Çalışma grubu üyelerinin ileri sürdüğü kültürel değerlerin, bilimsellik (f:5), dürüst ve adil olma (f:7), aile birliğine önem verme (f:6), vatanseverlik (5), estetik (f:5), saygı ve sevgi (f:10), duyarlılık (f:5), hoşgörü (f:12), temizlik ve sağlığa önem verme (f:10), barış (f:10), bağımsızlık (f:15), çalışkanlık ve yardımlaşma (f:10) olduğu gözlemlenmektedir (fig. 5). Sosyal bilgiler öğretmenlerinin ileri sürdükleri kültürel değerlerdeki bu çeşitlilik sosyal bilgiler dersi kazanımlarının kültürel yaşama katkı bakımından etkililik düzeyinin yüksek olduğunun göstergesi olduğu söylenebilir. Değerler incelendiğinde, bağımsızlık değerinin frekans olarak yüksek çıkması iki şekilde değerlendirilebilir. Birincisi, özgür düşünceye ve bu düşüncenin kültüre yansımasına olan inanç; ikincisi ise kendi değerlerinden başka, kültürel değerlere vatan toprakları üzerinde tahammül edememe duygusu. Tema ile ilgili çalışmada sosyal bilgiler öğretmenlerinin görüşlerinden birkaçı şu şekildedir:

"Sosyal bilgiler dersi genis alan tasarımını temele alarak hazırlanan bir ders olduğundan dolayl, dersin kazanımlarında birbirinden farklı birkaç kültürel değerin yer alması bana göre kaçınılmaz bir durumdur. Sosyal bilgiler dersi kazanımlarına bakıldı̆̆ında, daha çok bireyin kendini tanıma ve karakterini şekillendirmede etkili olan dürüstlük ve adalet değerlerinin ön plana çıktığını söyleyebilirim" (Sosyal Bilgiler Öğretmeni, 5; dürüst ve adil olma).

"Sosyal bilgiler dersi programlarında yer alan kazanımlarda ön plana çıkan kültürel değerler farklılı gösterse de bu değerlerin temelini oluşturan, toplum içerisinde bireyin sayginlık kazanmasında etkili olan en önemli değerlerden, sevgi ve saygının daha çok ön plana çıktı̆̆ın söyleyebilirim” (Sosyal Bilgiler Öğretmeni, 33; sevgi ve saygı).

"Sosyal bilgiler ders programında kültürel açıdan birçok değer ön plana çıksa da bu ders içerisinde farklı dine, ırka ve coğrafyaya mensup olupda birçok kültürel eser bırakan birey, topluluk veya devletlerin ortaya koymuş oldukları bu değerleri benimseyip korumay temele alı, gerektiğinde faydalanilabileceğini içeren hoş görünün daha da belirgin hale geldiğini söyleyebilirim” (Sosyal Bilgiler öğretmeni, 30; hoşgörü).

\section{Sonuç ve Tartışma}

$\mathrm{Bu}$ araştırmada, sosyal bilgiler dersi kazanımlarının kültürel yaşama etkisi konusunda sosyal bilgiler öğretmenleri ile yapılan görüşmelerde ulaşılan sonuçlar şu şekilde özetlenebilir: Sosyal bilgiler dersinin kültürel yaşam üzerinde etkili olduğu, sosyal bilgiler dersi kazanımlarının kültürel yaşamı etkilediği, sosyal bilgiler dersinde farklı öğrenme alanlarına yönelik kazanımların kültürel yaşam üzerinde etkili olduğu, sosyal bilgiler dersi kazanımlarında ön plana çıkan kültürel değerler (vatanseverlik, sevgi ve sayg1, estetik, aile birliğine önem verme, dürüst ve adil olma, bilimsellik, çalışkanlık ve yardımlaşma, bağımsızlık, barış, temizlik ve sağlığa önem verme, duyarlılık, hoşgörü) ve sosyal bilgiler dersi kazanımlarının ön plana çıkardığı öğrenme alanları (coğrafya, tarih, arkeoloji, sosyoloji, din, felsefe, eğitim) konusunda sosyal bilgiler öğretmenlerinin farklılaştığı çalışma bulgularında gözlemlenmektedir.

Çalışmanın temalarından birini oluşturan, sosyal bilgiler dersinin kültürel yaşam üzerindeki etkilerine ilişkin duruma yönelik, çalışmada elde edilen veriler incelendiğinde, çalışma grubu 
üyelerinin, sosyal bilgiler dersinin kültürel yaşam üzerindeki etkisine ilişkin gerekli farkındalığa sahip oldukları görülmektedir. Sosyal bilgiler öğretmenlerinin sosyal bilgiler dersi ile ilgili bu farkındalığa sahip olmaları, sosyal bilgiler öğretim programının vizyon şeması içeriğinde yer alan kültürel unsurlara sahip bireylerin yetişmesini kolaylaştırabilir. Sosyal Bilgiler Öğretim Programının vizyonu,"21. yüzyılın çağdaş, Atatürk ilkeleri ve inkılâplarını benimsemiş, Türk tarihini ve kültürünü kavramış, temel demokratik değerlerle donanmış ve insan haklarına saygll, yaşadiğl çevreye duyarl, bilgiyi deneyimlerine göre yorumlayı sosyal ve kültürel bağlam içinde oluşturan, kullanan ve düzenleyen (eleştirel düşünen, yaratıcı, doğru karar veren) sosyal katılım becerileri gelişmiş, sosyal bilimcilerin bilimsel bilgiyi üretirken kullandıkları yöntemleri kazanmış, sosyal yaşamda etkin, üretken, haklarını ve sorumluluklarını bilen, Türkiye Cumhuriyeti vatandaşlarını yetiştirmektir" (MEB, 2006, 25).

Çalışmada, sosyal bilgiler dersi kazanımlarının kültürel yaşamı etkileme konusunda çalışma grubunu oluşturan sosyal bilgiler öğretmenlerinin "evet" yanıtında birleşip, kendilerince alt nedenler oluşturmaları sosyal bilgiler dersinin kültürel yaşam üzerindeki etki düzeyinin güçlü olduğunu göstergesidir. Sosyal bilgiler öğretmenlerinin, kazanımların kültürel yaşam üzerindeki etkilerini kendi öğrencileri üzerinde farklı şekillerde gördüklerinden, soruya somut bir cevap verildiğini söyleyebiliriz. Sosyal bilgiler öğretmenlerine göre, bireyin kültürel yaşamını şekillendiren unsurlar, programların kazanımlarında ve içeriğinde yer alan değerlerdir. Sözer'in (1998) çalışmasında belirttiği "Sosyal Bilgiler dersinin önemli görevlerinden biri sosyal bilgiler programında yer alan temel değerlerin çocuklar tarafindan öğrenilmesini sağlayarak, kültürel ve demokratik yaşantıların onlara küçük yaşlardan itibaren kazandırılmasını sağlamaktır" ; Yaşar ve Çengelci'nin (2012) çalışmalarında belirttiği "sosyal bilgiler ögrencilere toplumsal ve kültürel yaşamın bilgi, beceri, tutum ve değerlerini kazandırmayı amaçlayan bir ders olarak değerler eğitiminde önemli görev ve roller üstlenmektedir" ş̧eklindeki ifadeleri, kültürel yaşamı şekillendiren değerlerin öğrenciye öğretilmesinin, sosyal bilgiler dersinin en önemli görevlerinden biri olarak belirtilmesi, çalışmada elde edilen sonucu desteklemektedir.

Sosyal bilgiler dersi öğretim programında "değer", "bir sosyal grup veya toplumun kendi varlık, birlik işleyiş ve devamını sağlamak ve sürdürmek için üyelerinin çoğunluğu tarafindan doğru ve gerekli oldukları kabul edilen ortak düşünce, amaç, temel ahlaki ilke ya da inançlar" (MEB, 2005, 87) olarak tanımlanmaktadır. Bu tanımdan hareketle, çalışmada, sosyal bilgiler dersi programlarında yer alan kazanımların içerdiği kültürel değerlere ilişkin, sosyal bilgiler öğretmenlerinin sahip olduğu algılar, bu dersin değer algısının önemini ortaya koymaktadır denilebilir. Ayrıca çalışmada elde edilen bu sonuç, Yaşar ve Çengelci'nin (2012) çalışmalarında "Sosyal Bilgiler dersinin diğer derslere oranla değerler eğitiminde daha ön planda olduğunu belirtmeleri” ve Kan'nın $(2010,140)$ "sosyal bilgiler dersi ve değerler eğitimi” isimli çalışmasında, "sosyal bilgiler dersi bir değer eğitimi dersidir. Gerek içeriğinin tarihsel bir nitelik taş-ması, gerekse değişik kültür ve yaşam hikâyelerini anlatması ve çok disiplinli bir yapıya sahip olması açısından değer öğretimi bakımından sosyal bilgiler dersi önemlidir" şeklinde ortaya koyduğu ifadelerle paralellik gösterdiği söylenebilir.

Sosyal bilgiler dersi programlarında yer alan kazanımların, kültürel yaşamı etkileme yönüne ilişkin çalışmada elde edilen sonuçlar incelendiğinde, ders kazanımlarının daha çok bireylerde "tarihsel sosyolojik analiz yapma" alt temasının çalışma grubu üyeleri tarafindan ön plana çıkarıldığını görmekteyiz. Bu temanın ön plana çıkması bireylerin, geçmişte yaşamış olan devletlerin, toplulukların, grupların ve bireylerin birbiri ile iletişimi, etkileşimi ve mücadelesi sonucu ortaya çıkan kültürel değerleri öğrenmeye olan ilgisinin ve merakının daha fazla olduğunun göstergesi olabilir. Ayrıca çalışmada bu bulgu ile ilgili elde edilen bir diğer alt temanın 
“artan ögrenme merakı" olması çalışmada elde edilen alt temalar arasındaki nedenselliği açıklaması bakımından önemlidir.

Sosyal bilgiler dersinin bilimsellik algısının sözel içerikten oluşmasının, pek çok çevre tarafindan tartışma konusu olduğu söylenebilir. Ancak, şu unutulmamalıdır ki sosyal bilgiler dersinin amaçlarından biri de öğrencilerde bilimsel düşünce becerilerini geliştirmektir (Gömleksiz, \& Cüro, 2011, 125). Buradan hareketle, çalışma grubu üyelerini oluşturan sosyal bilgiler öğretmenlerine göre, sosyal bilgiler dersi kazanımlarından ön plana çıkan kültürel değerlerden birinin bilimsellik olduğu, çalışma bulgularından elde edilmiştir. Elde edilen bu bulgu, Öztürk'ün (2007) yaptı̆̆ "küreselleşme ve bilgi çağında sosyal bilgiler öğretimi" isimli çalışmasında, "sosyal bilgiler dersi öğretim programının ögrencilerde bilimsel tutumu olumlu yönde geliştirdiği” bulgusu ile paralellik açısından desteklenebilir.

Sonuç olarak bu çalışmada elde edilen bulgulardan hareketle Türkiye'de sosyal bilgiler dersi kazanımlarının bireyin kültürel yaşamı üzerinde etkili olduğu konusunda sosyal bilgiler öğretmenlerinin ortak bir kanaate sahip oldukları gözlemlenmektedir (fig.1,2,3). Bu çalışmada elde edilen bulgulardan harketle şu önerilerde bulunabilir:

- Sosyal bilgiler ders programları oluşturulurken dersin vizyonu ve amacı dikkate alınarak, sosyal bilgiler çalışma alanı içerisinde yer alan bütün disiplinlere yönelik kültürel değerlere yer verilmelidir.

- Sosyal bilgiler dersi çalışma alanını oluşturan disiplinler ile ilgili çalışmalar yapılarak bu disiplinlerin bu çalışma alanına katkısı açıklanabilir.

- Sosyal bilgiler dersi kazanımları hazırlanırken kültürel değerleri ön plana çıkaran öğrenme etkinliklerine ders kitaplarında yer verilmelidir.

- Sosyal bilgiler dersinde kültürel yaşama yönelik hazırlanan kazanımlar konusunda kültürel değerlerin dünya üzerindeki farklı yansımalarına ilişkin görsellere içerik kısmında yer verilmelidir.

- Sosyal bilgiler dersi programı hazırlanırken kültürel anlamda farklılıkların kazanımlarda yer almasına dikkat edilmelidir.

- Sosyal bilgiler öğretmenleri kültürel yaşama yönelik hazırlanan kazanımların aktarımında tarafsızlık ilkesi çerçevesinde hareket etmelidirler. 


\section{KAYNAKÇA}

Balcı, A. (2004). Sosyal Bilimlerde Araştırma, Yöntem, Teknik ve Illkleler. Ankara: Pegem Akademi Yayınları.

Becker, G. (2001). Unterricht Planen Handlungsorientierte Didaktik. Weinheimund Basel: Beltz Paedagogik.

Creswell, J. W. (1998). Qualitative Inquiry and Research Design: Choosing Among Five Traditions. Thousand Oaks, CA: Sage Publications.

Deveci, H., \& Bayır, G. Ö. (2011). "Hayallerdeki Sosyal Bilgiler: İlköğretim Üçüncü Sınıf Öğrencilerinin Algiları". Uluslararast Avrasya Sosyal Bilimler Dergisi, 2/4, 9-28.

Doğanay, A. (2003). "Sosyal Bilgiler Öğretimi”. Eds.: C. Öztürk, \& D. Dilek. Hayat Bilgisi ve Sosyal Bilgiler Ögretimi. Ankara: Pegem A Yayıncılık.

Duplass, J. A. (2007). “Elementary Social Studies: Trite, Disjointed, and in Need of Reform?”. The Social Studies, 98/4, 137-144.

Engle, S., \& Ochoa, A. (1988). Education for Democratic Citizenship: Decision Making in the Social Studies. New York: Theachers Collage Press.

Ertürk, S. (1972). Eğitimde "Program” Geliştirme. Ankara: Hacettepe Üniversitesi Yayınları.

Hogg, M. A., \& Vaughan, G. M. (2007). Social Psychology. New York: Prentice Hall.

Kağıtçıbaşı, Ç. (2010). Benlik, Aile ve İnsan Gelişsimi-Kültürel Psikoloji. Koç Üniversitesi Yayınları.

Kan, Ç. (2010). "Sosyal Bilgiler Dersi ve Değerler Eğitimi”. Milli Eğitim Dergisi, 187, 138-145.

Kottak, C. P. (2008). Antropoloji Insan Çeşitliliğine Bir Baklş. Çev.: S. N. Altuntek et alii. Ankara: Ütopya Yayınları.

Malinowski, B. (1945). The Dynamics of Culture Change. New Haven: Yale University Press. Çev.: M. Turhan (1987). Kültür değişmeleri, 49. İstanbul.

MEB. (2005). İlköğretim Sosyal Bilgiler Dersi 4-5 Sinıf Öğretim Programı ve Kılavuzu. Ankara

MEB. (2006). İlköğretim Sosyal Bilgiler Dersi 6 Sinı Öğretim Programı ve Kılavuzu. Ankara.

Mentiş, T. A. (2004). "Sosyal Bilgiler Öğretmenliği Eğitimi Program Standartlarının Belirlenmesi”. Ankara Üniversitesi Eğitim Bilimleri Fakültesi Dergisi, 37/1, 28-54.

Merriam, S. (1998). Qualitative Research and Case Study Applications in Education. San Francisco: Jossey-Bass.

Miles, M., \& Huberman, A. (1994). Qualitative Data Analysis: An Expanded Source Book. Thousand Oakes: Sage Publications.

Mutlu, T. O. (2013). "Investigating Organizational Culture Perception of Students Studying in School of Physical Educationand Sports in Turkey”. Educational Research and Reviews, 8/12, 815-821.

National Council for the Social Studies (1994). Curriculum Standards for Social Studies. Washington DC.

Öztürk, C., \& Dilek, D. (2003). "Hayat Bilgisi ve Sosyal Bilgiler Öğretim Programları”. Eds.: C. Öztürk, \& D. Dilek. Hayat Bilgisi ve Sosyal Bilgiler Öğretimi. Ankara: Pegem A Yayınc1lık.

Saban, A. (2008). "Okula İlişkin Metaforlar”. Kuram ve Uygulamada Eğitim Yönetimi, 55, 459-496.

Safran, M. (2008). "Sosyal Bilgiler Öğretimine Bakış”. Eds.: B. Tay, \& A. Öcal. Özel Öğretim Yöntemleriyle Sosyal Bilgiler Öğretimi. Ankara: Pegem A Yayıncılık.

Sözer, E. (1998). "Sosyal Bilgiler Programının Amaçları, İlkeleri ve Temel Özellikleri”. Ed.: Gürhan Can. Sosyal Bilgiler Öğretimi, 15-39. Anadolu Üniversitesi Yayınları/1064. Açıköğretim Fakültesi Yayınlar1/581. Eskişehir: Anadolu Üniversitesi, Web- Ofset Tesisleri.

Talas, M. (2010). Sosyoloji. Eds.: F. Merter, \& M. Talas. İstanbul: Lisans Yayınları.

Tezcan, M. (1987). Kültür ve Kişilik (Psikolojik Antropoloji). Ankara: Bilim Yayınları.

Ulusoy, K. (2009). "Yenilenen Sosyal Bilgiler Programında Tarih Öğretimi”. Eds.: R. Turan et alii. Sosyal Bilgiler Öğretiminde Yeni Yaklaşımlar-1. 299-321, Ankara: Pegem A Yayıncılık.

Ulusoy, K. (2009). "Sosyal Bilgiler Dersi Kültür ve Miras Öğrenme Alanının İşlenişinin 4. ve 5. Sınıf Öğrencileri Tarafından Değerlendirilmesi”. Akademik Bakış Dergisi, 18, 153-178. ISSN:1694-528X. 
Ültanır, G. (2003). "Eğitim ve Kültür İlişsisi-Eğitimde Kültürün Hangi Boyutlarının Genç Kuşaklara Aktarılacağı Kaygısı". Gazi Eğitim Fakültesi Dergisi, 3/23, 3291-309.

Varış, F. (1994). Eğitimde Program Geliştirme Teori ve Teknikleri. Ankara: Alkım Kitapçılık Yayıncılık. Wade, R. C. (2007). Social Studies for Social Justice. Amsterdam: Teachers College Press.

Yaşar, Ş., \& Çengelci, T. (2012). Sosyal Bilgiler Eğitiminde Değerler Eğitimine İlişkin Durum Çalışması. Uluslararasl Avrasya Sosyal Bilmler Dergisi, 3/9, 1-23.

Yııldırm, A., \& Şimşek, H. (2008). Sosyal Bilimlerde Nitel Araştırma Yöntemleri. Ankara: Seçkin Yayıncılık. Yin, R. K. (1994). "Evaluation: A Singular Craft”. Eds.: C. Reichardt and S. Rallis. New Directions in Program Evaluation, 1994, 71-84. 